\title{
PSYCHOLOGICAL FACTORS OF SUBJECTIVE WELL-BEING OF ADOLESCENTS IN CONDITIONS OF A SPECIALIZED BOARDING SCHOOL
}

Yezerska Natalia

https://orcid.org/0000-0002-7311-3845

\begin{abstract}
An empirical study of the psychological factors of subjective well-being of adolescents was carried out with the help of observation, conversation and such psycho-diagnostic techniques as: "The subjective well-being questionnaire" (O. Vlasova); "Test "Determination of the personal adaptation of schoolchildren” (A. Furman); "The person orientation inventory questionnaire (POI, E. Shostrom)”; «Methodology» Anxiety scale «(J. Taylor); «Methodology» Definition of the general emotional orientation of the individual «(B. Dodonov); Technique «Man in the rain» (O. Romanova, T. Sytko); author's questionnaire, which helped to determine the adolescents subjective view of happiness. Statistical data processing was performed by using the capabilities of the SPSS-21 computer program.

Experimental work was carried out during 2013-2017 on the basis of Kyiv educational institutions. The total number of subjects covered 400 students of the 8th -9th grades studying with indepth study of physics and mathematics.

The students of physical and mathematical lyceums have an anxiety level corresponding to the age standards, the greatest is the indicator of self-assessed anxiety, the leading emotional orientation is romantic, praxical, gnostic and communicative, have an average level of self-actualization and an obvious level of personal non-adaptability. Subjective well-being is at an average level and has links with personal adaptability and altruistic emotional orientation. Girls, compared to boys in terms of learning exact sciences, are more romantically and aesthetically emotionally oriented, with a higher personal growth.

The main factors of subjective well-being of students of physical and mathematical lyceums are personal adaptation, gnostic and altruistic orientation, low level of school anxiety and a high level of self-actualization.

The study of subjective well-being of the students of physical and mathematical lyceums has helped to establish the close interdependent connection between personal adaptability, self-actualization, altruistic and praxical emotional orientation and subjective well-being of students. In addition, the level of subjective well-being is most influenced by its components as a goal in life, self-perception and positive attitude. An important factor is a respondent's accommodation or non-accommodation in hostel, because it may affect his|her subjective characteristics, the formation of personal traits and relationships with others. Under studying the adolescents the basic psychological peculiarities, depending on the education form, it is established that adolescents studying in the institution of the residential type of the physical and mathematical direction have an average level of anxiety, with predominance of selfassessed anxiety. Practical, romantic and gnostic emotional orientations have a non-obvious level of personal non-adaptability, average level of self-actualization, high level of subjective well-being and its components, such as personal growth and positive attitude.
\end{abstract}

Keywords: subjective well-being, psychological well-being, factors, adolescents, giftedness, psychological support, adaptation, specialized boarding school.

\section{Introduction}

In today's society, the psychological support of a gifted child is an important task of our country. Each child needs an individual approach, help in disclosing her|his endowments, forming an integral, harmonious personality. This goal brings teachers and psychologists' attention to the difficult tasks of requiring a structural, systematic and consistent solution. The need to study the psychological factors of subjective well-being of students is due to a large number of sociopsychological problems, accompanying process of boarding school socialization of gifted adolescents, which are favourable to increase the anxiety and aggression.

The purpose of the research is to theoretically substantiate and empirically investigate the influence of psychological factors of subjective well-being of gifted adolescents on 
the process of adaptation to the conditions of a specialized boarding school.

It is accepted to differentiate two approaches to the problem of subjective well-being: hedonistic and eudemontistic. The hedonistic theories are those where well-being is described in terms of satisfaction / dissatisfaction, such as M. Argyla (Arhail, 2003). The eudemontistic understanding is based on the postulate that personal growth - the main necessary object of well-being in the opinion of K. Riff (Ryff, 1995). This approach operates with the concepts of "psychological well-being" or "eudemontic well-being".

Both approaches try to answer the question "what is happiness?". It is transfered from the philosophical and everyday category to the scientific and methodological, but they come from conceptually different points of view on the personality and his|her life activity. The eudemonic approach emphasizes the peculiarities of the individual necessary for a positive functioning, which means the continuation of his|her development; we can define it as a personpsychological one. The hedonic approach focuses more on the social circumstances of life and the influence of society on how a person evaluates the content of his|her own existence, and its positiveness is considered as the state of satisfaction of needs, that is, such a vision can be regarded as a socio-psychological.

In a series of works it is described the relationship of psychological well-being with different aspects of human existence. It is described the aspects of positive functioning. (O.Vlasova (Vlasova, 2005), T. Danylchenko (Danylchenk, 2015: 57-62)), however, there is no single position regarding the content of the positive functioning of the individual (there are different views on the ratio of basic concepts of hedonistic and eudemonic approaches - their identification.

L. Naydionova (Naidonova, 2007: 10-19) also points to the impossibility of determining the well-being of an individual in terms of abstraction from the well-being of the community to which this person belongs. M. Chiksentmikai (Chyksentmykhaiy, 2011) argues that the experience of happiness is possible when a person is involved in the activity that captures it, is in a state of "flow".
Subjective-behavioral approach in modern psychology involves the understanding of man as a holistic integrated creature being capable of committing a deed as a highly moral, responsible, free, creative act, which is a way of authentic existence. Subjectivity foresees the position of the creator of his|her own life path by $\mathrm{T}$. Titarenko (Tytarenko, 2014). Specifics of socialization of gifted teenagers are disclosed in the works of K.Milyutinoy (Miliutina, 2014) and O.Musiki (Muzyka, 2014: 213-228).

Therefore, the socio-psychological factors of subjective well-being of teenagers to the boarding schools' conditions, we choose the individual sphere of a teenager, motivation, selfactualization, general emotional orientation, selfperception, socio-psychological relationships.

\section{Methodology}

A total of 400 students-teenagers (13-15 years) participated in the research. The research base was promoted at the Ukrainian Physics and Mathematics Lyceum of the Taras Shevchenko National University of Kyiv (300 students, among them 150 lived in a hostel) and 100 students of the Rusaniv Lyceum of the Dnipro district in Kyiv.

\section{Results}

The study of general subjective well-being by Pearson's correlation method revealed the strongest positive correlation between independent parameters, namely: with the scale "goals in life" ( $\mathrm{r}=0.620 * *$ at $\mathrm{p}<0.01$ ); with the scale of "selfadmission" ( $\mathrm{r}=0.603 * *$ at $\mathrm{p}<0.01)$; with an independent parameter on the scale of "personal adaptability" ( $\mathrm{r}=0,435 * *$ at $\mathrm{p}<0,01)$; with the scale of "personal growth" $(\mathrm{r}=0,426 * *$ at $\mathrm{p}$ $<0,01$ ); with an independent parameter of the scale "praxis emotion" ( $\mathrm{r}=0,339 * *$ at $\mathrm{p}<0,01)$; with the scale of "autonomy" $(\mathrm{r}=0,295 * *$ at $\mathrm{p}<0,01)$; with an independent parameter of the scale "Gnostic Emotion" ( $\mathrm{r}=0,291 * *$ at $\mathrm{p}<0,01)$; with a scale of "positive environment" $(\mathrm{r}=0,273 * *$ at $\mathrm{p}<0,01)$; with the scale of "management of others" ( $\mathrm{r}=0,269 * *$ at $\mathrm{p}<0,01)$; with an independent parameter of the scale "altruistic emotion" ( $\mathrm{r}=$ $0.259 * *$ at $\mathrm{p}<0.01$ ); with an independent parameter of the scale "communicative emotion" $(r=0,206 *$ at $\mathrm{p}<0,05)$; with an independent parameter of the scale "self-actualization" ( $\mathrm{r}=$ $0.194 *$ at $\mathrm{p}<0.05)$. There was no negative correlation connection. 


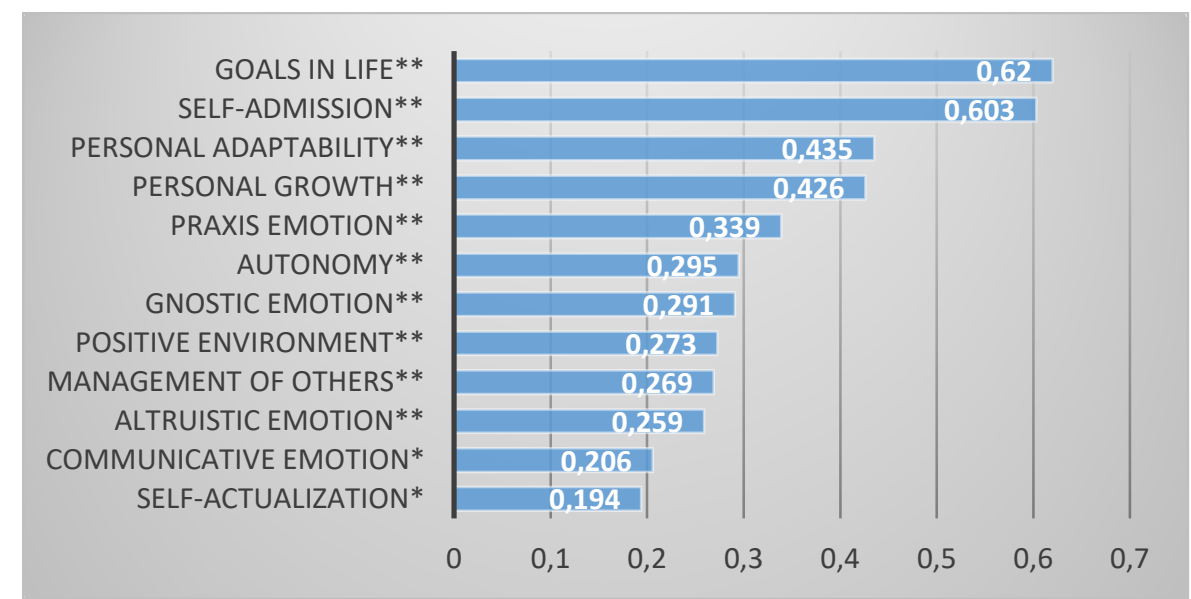

Fig. 1. Factors' distribution of subjective well-being by relevant connections $(\mathbf{p}<\mathbf{0 , 0 1})$.

Through the examination, the subjective view of teenagers' happiness was determined for the physics and mathematics direction of learning and its ways of achieving.

\section{Descriptors of happiness}

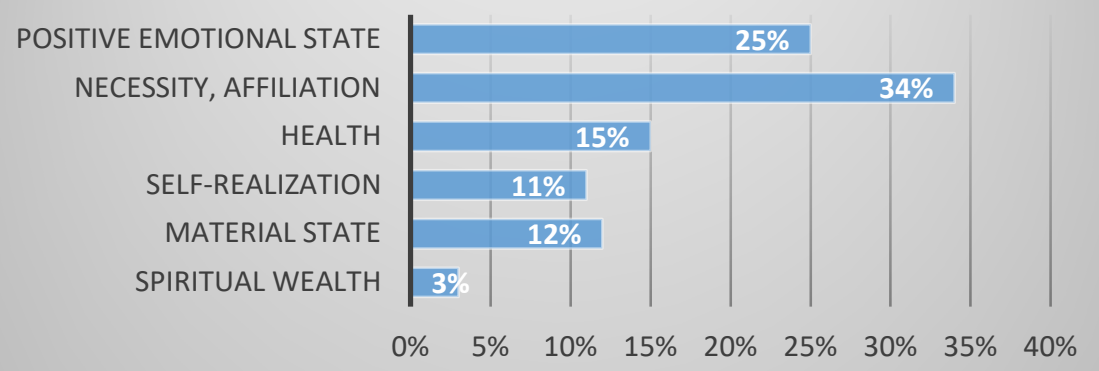

Fig. 2 The main descriptors of happiness after teenagers' presentation

Most adolescents (34\%) believe that happiness is a necessity for loved ones and belonging to a group. Happiness for them is to have good relations with relatives, to have friends, to have their own family, to love and to be loved. This is a logical result, because in adolescence, intimate-person communication is a leading activity. $25 \%$ of respondents believe that happiness consists of joy feelings and satisfaction with life, which determine the elevated emotional state. The factors of happiness here were called the ability to enjoy life, not to be oppressed because of problems. Strong health as a sign of happiness was in third place (15\% of responses). $12 \%$ of respondents think that happiness is a lack of material problems. Among the factors of happiness through the prism of the material were called "roof overhead", a lot of money, a career with a high income. $11 \%$ are sure that happiness is self-actualization. Spiritual wealth as a synonym of happiness is considered by only $3 \%$ of the subjects. Spirituality takes the lowest steps in the value structure of youth ideas of happiness, which in general reflects the current orientation of society: to get maximum pleasure from consumption.

The question of ways to achieve happiness was too complicated for many interviewed: $30.3 \%$ of adolescents did not answer it.

Most teenagers believe that in order to achieve happiness it is necessary to choose a goal and constantly move to it (18.7\%). $13.3 \%$ of the respondents answered that happiness can be achieved through success. $11.5 \%$ of respondents think that the way to achieve happiness is to enjoy life every day. Another significant part of adolescents is convinced that the path to happiness is to help other people (10.5\%).

Thus, the questionnaire on ways to achieve happiness and the basic descriptors of happiness for adolescent ideas coincide with our theoretical model of factors of subjective well-being of students (Fig. 1). 


\section{Ways to achieve happiness}

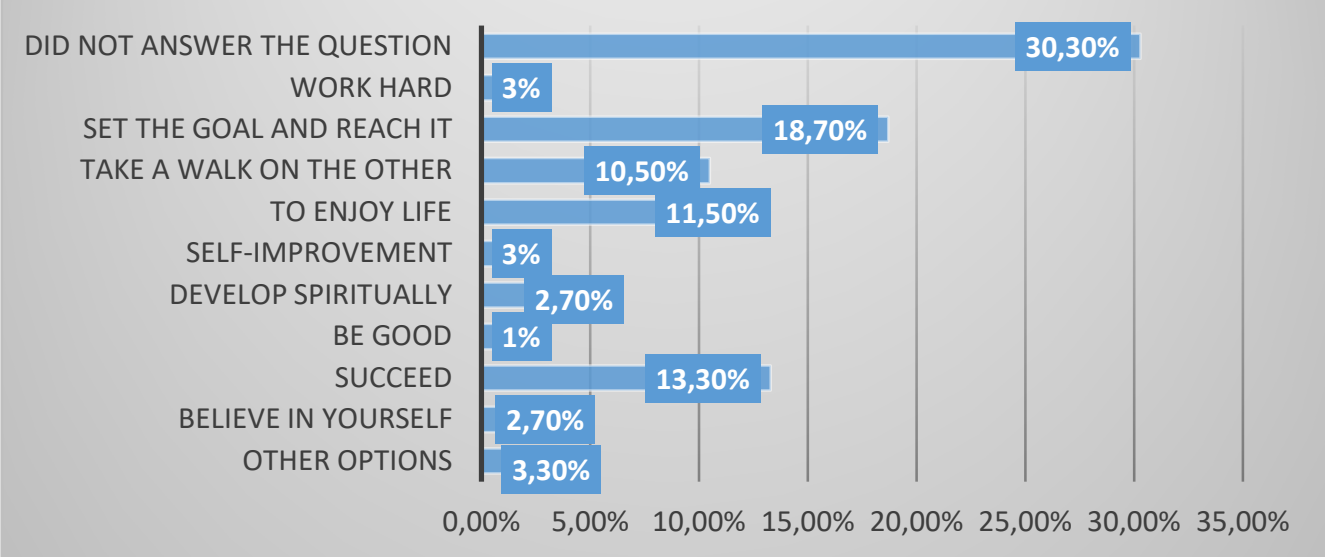

Fig.3 Representation of adolescents about ways to achieve happiness

1) in the motivational sphere, adolescents consider it necessary: to set goals, to work hard, to succeed, to self-fulfillment;

2) in the individual sphere, according to adolescents, it is necessary: to enjoy life, to care for others, to be kind, to be in a positive emotional state, to be healthy, to be independent (autonomous);

3) As to the sphere of socio-psychological relationships, adolescents point out that it is important: to believe in oneself, to be necessary, to develop spiritually, to self-improvement.

As a result of the mathematical and statistical analysis of the data obtained during the study, it was established that students of physical and mathematical lyceums have a normal level of anxiety and its components, the greatest is the indicator of self-esteem anxiety, the leading emotional orientation is romantic, praxical, gnostic and communicative, have an average level of self-actualization and the obvious level of personal non-adaptability. Subjective well-being at an average level has links with personal adaptability and altruistic emotional orientation. Girls, compared with boys in terms of learning exact sciences, are more romantically and aesthetically emotionally oriented, with a higher personal growth.

The main factors of subjective well-being of students of physical and mathematical lyceums are personal adaptation, gnostic and altruistic orientation, low level of school anxiety and high level of self-actualization.

Investigation of the correlation of subjective well-being of students of physical and mathematical lyceums helped to establish the close interdependent connection between personal adaptability, self-actualization, altruistic and praxis emotional orientation and subjective wellbeing of students (Fig. 5). In addition, the level of subjective well-being is most influenced by its components as a goal in life, self-perception and positive attitude. Consequently, in the personadapted to a team that has a tendency to selfactualization with high probability one can speak of high subjective well-being.

An important factor is the residence or nonresidence of the respondent in the hostel, as it may affect his|her subjective characteristics, the formation of personality traits and relationships with others. In order to determine the presence, strength and peculiarities of the influence of factors of subjective well-being, depending on the hostel, a comparison of the two groups was initially performed first on the average indicators, and then the determination of statistically significant difference of these two parameters between the two groups.

In the study of the main psychological characteristics of adolescents, depending on the form of education, it is established that adolescents studying in a residential type of physical and mathematical direction have an average level of anxiety, with a predominance of self-assessed anxiety, have a praxical, romantic and gnostic emotional orientation, have a non-obvious level of personal non-adaptation , the average level of selfactualization, the high level of subjective wellbeing and its components, such as personal growth and positive attitude. 


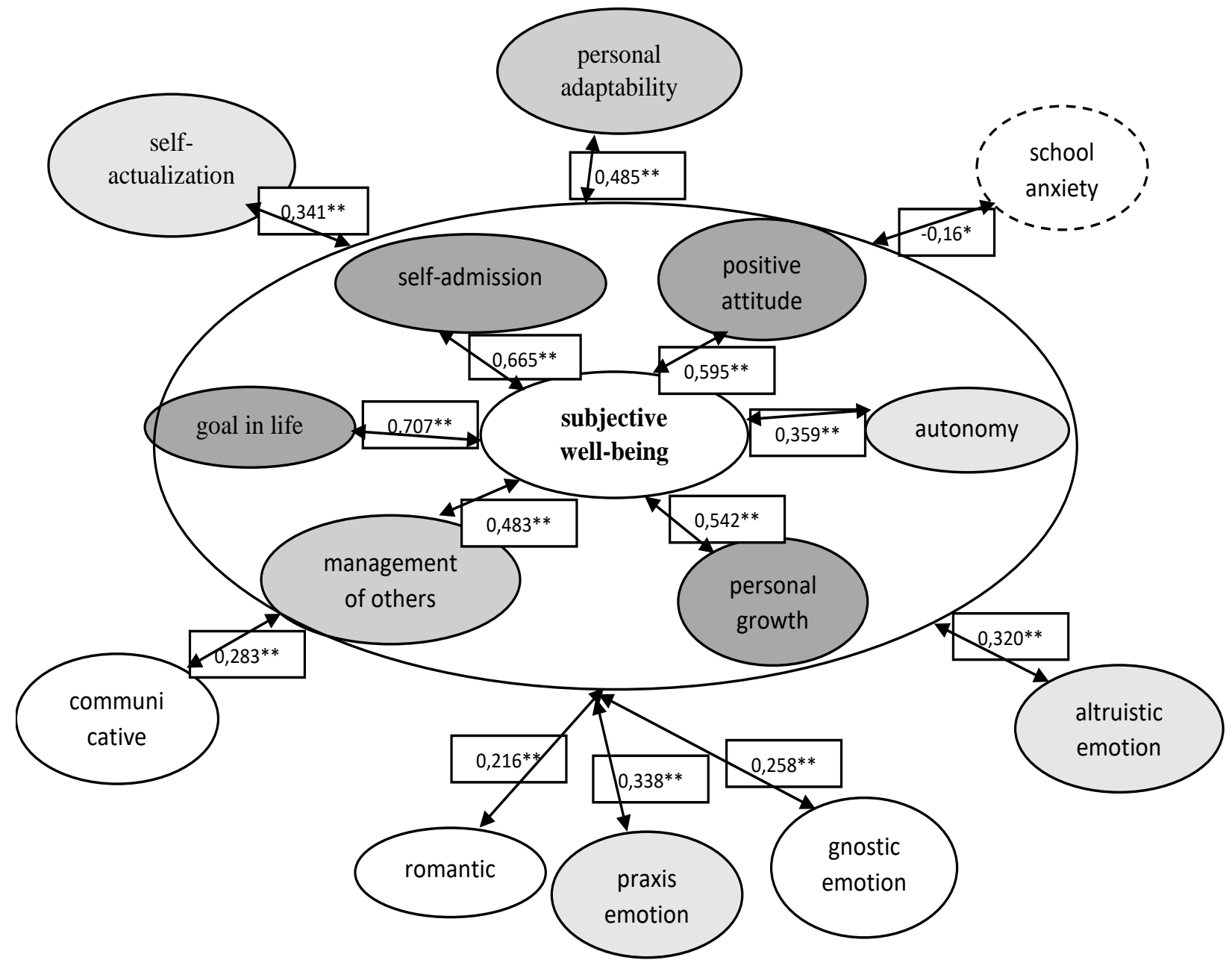

Fig. 4. Correlation galaxy of connections of subjective well-being of mathematically gifted teenagers

Double-point cluster analysis was used to adaptation to the educational process, the second determine the main factors affecting the unadapted students (according to the classification adaptability and subjective well-being of students. of A.Furman's method itself, according to which Two clusters were identified during the analysis, the threshold value of the adaptability distinction the first ones were those who had satisfactory was 57 points) (Fig. 6 )

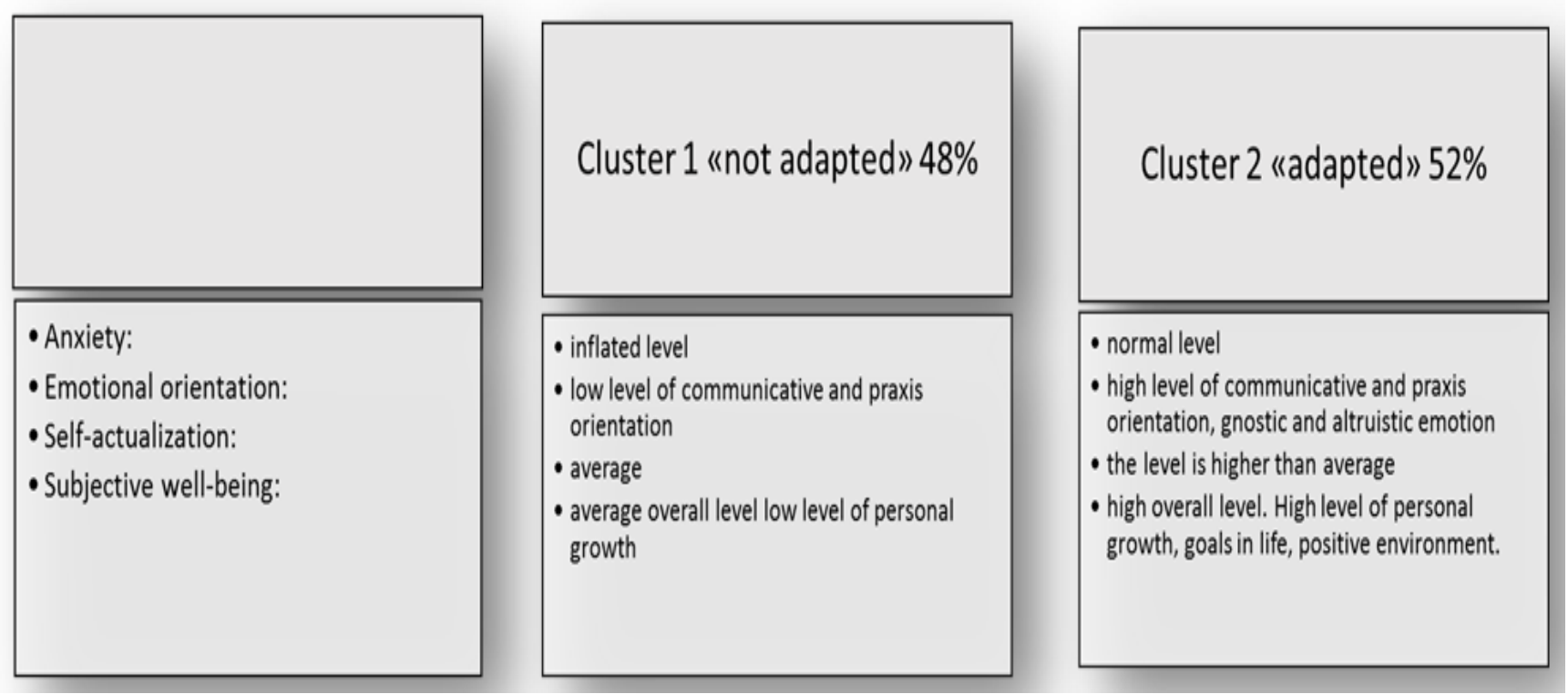

Fig. 5. Components of clusters regarding students' adaptability 
As a result of a two-stage cluster analysis, it was found that the first cluster (group) included those students who had satisfactory adaptation to the educational process, the second - unadapted students. Thus, we can say that adapted students are characterized by high levels of praxis, altruistic, gnostic, and communicative orientation, which affects: self-actualization and subjective well-being, which, in turn, allow us to assume that as a result of the development of emotional orientation thanks to formation program the personality will be able to form and develop such own qualities as: personal responsibility, selfknowledge, autonomy, etc.

Thus, we can say that adapted children are characterized by high indicators of praxis, altruistic, gnostic and communicative orientation, self-actualization and subjective well-being, personal growth, the presence of goals in life and positive attitudes towards others, and low levels of anxiety. Therefore, to increase adaptability and subjective well-being, as its direct dependent element, psychologists of primary institutions should pay attention to these indicators, reinforcing them through training psychological exercises. With that end in view, a program of social and psychological support for the adaptation of gifted adolescents in a specialized boarding school was developed.

\section{Conclusion}

It has empirically been determined the factors of subjective well-being of gifted teenagers in a specialized boarding school: low general anxiety, high self-actualization and altruistic emotional orientation. At the same time, the low level of school anxiety and adaptability is added to the main factors of subjective well-being of students of physical and mathematical lyceums of full-time education.

It is proved that adapted children are characterized by high indicators of praxis, altruistic, gnostic and communicative orientation, self-actualization and subjective well-being, personal growth, the presence of goals in their life and positive attitudes towards others, as well as low indicators of anxiety.

The prospects for further research are seen in further scientific research which may concern the study of the factors of subjective well-being of gifted students at different age stages; the study of the peculiarities of subjective well-being of students studying in the humanities, the expansion of possible factors of adaptability and well-being of adolescents in the development of new methods for psychological analysis and improvement of diagnostic and correction methods.

Conflict of interest. We state that there is no conflict of scientific interests.

\section{References}

Arhail M. (2003). Psykholohyia schastia [Psychology of happiness] / M. Arhail; per. s anhl. A. Lysytsyna. - SPb.: Pyter, 271 . [in Russian]

Vlasova O.I. (2005). Psykholohiia sotsialnykh zdibnostei: struktura, dynamika, psykholohichni chynnyky rozvytku: monohrafiia [Psychology of social capabilities: structure, dynamics, factors of development: monograph] / O.I. Vlasova. - Kyiv: Kyivskyi universytet, 307 p. [in Ukrainian]

Danylchenko T.V. (2015). Metodychni problemy vyvchennia subiektyvnoho sotsialnoho blahopoluchchia [Methodical problems of study of subjective social prosperity]/ T.V. Danylchenko . Visnyk Chernihivskoho natsionalnoho pedahohichnoho universytetu. Seriia: Psykholohichni nauky [Announcer of the Chernihiv national pedagogical university. Ser. Psychological sciences], 126, pp. 57-62. [in Ukrainian]

Miliutina K.L. (2014) Vplyv sotsialnoho otochennia na rozvytok osobystosti obdarovanoho pidlitka [Influence of social surroundings is on development of personality of the gifted teenager] / K.L. Miliutina. Osvita ta rozvytok obdarovanoi osobystosti [Education and development of the gifted personality], 11(30), pp.73-76. [in Ukrainian]

Muzyka O.L. (2014). Vzaiemodiia potreb i zdibnostei u rozvytku tvorcho obdarovanoi osobystosti [Co-operation of necessities and abilities is in development of the creatively gifted personality]/ O.L. Muzyka. Aktualni problemy psykholohii: Zbirnyk naukovykh prats Instytutu psykholohii imeni H.S. Kostiuka NAPN Ukrainy [Issues of the day of psychology : Collection of scientific works of G.S. Kostiuk Institute of Psychology of the National Academy of Educational Sciences of 
Ukraine]. $\quad-\quad$ K.: Feniks, T.KhII. Psykholohiia tvorchosti [Psychology of creativity] - Vypusk 20. - pp. 213-228. [in Ukrainian]

Naidonova L. (2007). Psykholohichne blahopoluchchia liudyny

[Psychological prosperity of man] / L.A. Naidonova. Dyrektor shkoly. Ukraina, 2,1019.

Tytarenko T.M. (2014). Psykholohichni praktyky konstruiuvannia zhyttia $\mathrm{V}$ umovakh postmodernoi sotsialnosti: monohrafiia

[Psychological practices of constructing of life in the conditions of postmodern sociality: monograph] / T.M. Tytarenko, O.M. Kochubeinyk, K.O. Cheremnykh. - K.: Milenium, 206 s.

Chyksentmykhaiy M. (2011). Potok. Psykholohyia optymalnoho perezhyvanyia [Psychology of the optimal experiencing]/ M. Chyksentmykhaiy; per. E. Perovoi. Moskow: Alpyna-non-fykshn,. 464 s.

Ryff C. (1995). The Structure of Psychological Well-Being Revisited / C.D. Ryff, C.L.M. Keyes. Journal of Personality and Social Psychology. - Vol. 69, No. 4. - P. 719-727. 